\title{
PENGARUH KUALITAS LAYANAN DAN NILAI PELANGGAN TERHADAP KEPUASAN PELANGGAN GRAB BIKE DI UNIVERSITAS KRISNADWIPAYANA
}

\author{
David Adista ${ }^{1)}$ \\ 1) Mahasiswa Program Studi Manajemen FE UNKRIS \\ Donny Dharmawan 2) \\ 2) Dosen Program Studi Manajemen FE UNKRIS \\ Alamat: Kampus UNKRIS, Jatiwaringin Jakarta Timur \\ Email : donnydh28@gmail.com
}

\begin{abstract}
This study aims to analyze the effect of service quality and customer value on GrabBike customer satisfaction at Unkris, Jakarta. This study took a sample of 71 customers from a total of 250 GrabBike customers at Unkris, Jakarta. Samples were taken using the Slovin formula by random sampling method. Data testing techniques used in this study include validity test, reliability test, multiple linear regression analysis to test and prove the research hypothesis. The results of this analysis indicate that the variables of service quality and customer value have a positive and significant influence on customer satisfaction.
\end{abstract}

Keywords: Service quality, customer value, customer satisfaction

\section{PENDAHULUAN}

Dalam dunia perekonomian di Indonesia saat ini, transportasi menjadi salah satu penunjang penting berbagai macam aktifitas manusia dalam memenuhi kebutuhan sehari-hari. Transportasi merupakan suatu alat bantu atau prasarana bagi manusia atau barang yang timbul akibat adanya kegiatan disuatu daerah. Selain itu, transportasi mampu menunjang perekonomian yang baik disuatu daerah maupun disuatu negara. Semakin baik dan tertatanya transportasi disuatu daerah maka semakin baik juga pertumbuhan perekonomiannya. Salah satu daerah perkotaan dengan tingkat pertumbuhan transportasi dan diikuti dengan tingkat penduduk yang tinggi adalah DKI Jakarta. Jakarta sebagai ibu kota negara Indonesia menjadi salah satu roda pertumbuhan perekonomian di Indonesia. Dengan meningkatnya pertumbuhan penduduk dan transportasi di Jakarta, maka timbul berbagai macam masalah salah satunya adalah masalah kemacetan.

Dalam Detik Oto yang dikutip dari situs Tomtom Index, Jakarta menduduki peringkat ketiga sebagai kota paling macet di dunia pada tahun 2017. Berbagai cara dilakukan dalam mengatasi masalah kemacetan di kota Jakarta salah satunya adalah berfokus pada layanan publik berupa transportasi umum. Dengan adanya pilihan transportasi umum, diharapkan pengguna kendaraan pribadi beralih ke transportasi umum dan dapat mengurangi kemacetan di Jakarta.

Dengan adanya masalah kemacetan tersebut, semakin banyak pelaku bisnis penyedia jasa transportasi baik berskala besar maupun kecil harus mampu memenuhi kebutuhan pelanggannya dengan memberikan layanan yang lebih baik dan berinovatif. Inovasi tidak hanya sekedar proses penciptaan sesuatu yang baru, tetapi juga merupakan produk aktual atau outcome (hasil).

Seiring berkembangnya teknologi informasi saat ini, para pelaku bisnis transportasi melakukan inovasi yaitu dengan memanfaatkan penggunaan teknologi internet dalam menjalankan bisnisnya tersebut. Saat ini perkembangan internet terjadi sangat cepat dan fleksibel dalam mendapatkan suatu informasi. Berdasarkan survey yang dilakukan oleh 
Asosiasi Penyelenggara Jasa Internet Indonesia (APJII), populasi penduduk indonesia saat ini sekitar 262 juta orang. Lebih dari 50 persen atau sekitar 143 juta orang telah menggunakan jaringan internet pada tahun 2017. Mayoritas pengguna internet sebanyak 72,41 persen masih dikalangan masyarakat urban. Penggunaannya pun sudah lebih jauh yaitu tidak hanya terbatas pada pemanfaatan informasi melalui media saja, tetapi dapat juga digunakan sebagai sarana untuk melakukan transaksi perdagangan yaitu berupa Electronic Commerce atau dikenal dengan istilah E-Commerce. E-Commerce merupakan kegiatan perdagangan barang atau jasa yang berhubungan dengan konsumen dengan menggunakan media elektronik berupa internet. E-commerce memiliki beberapa kelebihan yaitu dapat memberikan layanan dan informasi secara cepat tanpa ada batasan waktu, dan meningkatkan efisiensi proses bisnis. Di Indonesia terdapat banyak perusahaan yang memanfaatkan E-Commerce salah satunya transportasi online. Transportasi online mulai mengalami perkembangan pada pertengahan tahun 2015, dimulai dengan munculnya Go-jek, Grab, dan Uber. Tingginya minat konsumen terhadap transportasi online menyebabkan semakin ketatnya persaingan dalam eksistensi perusahaan untuk menciptakan kualitas layanan dan nilai pelanggan dalam menciptakan kepuasan pelanggan.

Kepuasan pelanggan adalah perasaan senang ataupun kecewa yang muncul setelah membandingkan antara kinerja atau hasil suatu produk terhadap hasil atau kinerja yang diharapkan (Kotler dan Keller, 2014). Jika kinerja atau hasil yang diharapkan tidak sesuai dengan yang diharapkan, maka akan muncul rasa ketidak puasan pada konsumen. Sedangkan jika kinerja atau hasil yang diharapkan sudah sesuai dengan yang diharapkan, maka akan timbul rasa kepuasan pada konsumen. Puas atau tidaknya konsumen merupakan respon yang ditunjukkan oleh konsumen terhadap evaluasi dari ketidaksesuaian yang dapat dirasakan antara harapan sebelumnya dengan kinerja suatu produk atau jasa yang dirasakan setelah penggunaannya. Oleh karena itu perusahaan harus mulai mempertimbangkan akan pentingnya layanan secara intensif melalui kualitas layanan, karena saat ini makin disadari bahwa layanan merupakan aspek penting dalam rangka mempertahankan suatu bisnis dalam memenangkan persaingan.

Sebelum konsumen memutuskan untuk merasa puas terhadap suatu produk atau jasa, ada beberapa faktor yang menjadi pertimbangan yaitu kualitas layanan. Menurut Tjiptono (2014), kualitas layanan adalah ukuran seberapa baik tingkat layanan yang mampu diberikan kepada pelanggan sesuai dengan ekspektasinya. Kualitas layanan merupakan segala aspek jasa atau layanan yang disampaikan suatu perusahaan dengan tujuan memenuhi ekspektasi para pelanggan berupa kemudahan, kecepatan, kemampuan, hubungan, dan keramahan dalam melakukan transaksi jual beli.

Selain itu, sebelum pelanggan memutuskan untuk memilih produk atau layanan dari produsen atau penyedia jasa layanan, pelanggan terlebih dahulu akan membandingkan tawaran mana yang menghantarkan nilai pelanggan yang baik. Seorang pelanggan yang merasa puas adalah pelanggan yang merasa mendapatkan nilai atau value dari produsen atau penyedia jasa. Menurut Tjiptono (2011), nilai pelanggan merupakan keseluruhan penilaian pelanggan tentang kegunaan suatu produk berdasarkan persepsi tentang apa yang diterima dan apa yang diberikan. Berdasarkan definisi tersebut, maka nilai pelanggan berkaitan dengan proses memberi dan menerima yang dialami oleh pelanggan. Jika manfaat yang diterima lebih tinggi dari biaya yang dikeluarkan maka pelanggan akan merasa puas. Begitu juga sebaliknya, jika manfaat yang diterima lebih kecil dari biaya yang 
dikeluarkan maka pelanggan akan merasa tidak puas atau kecewa.

PT. Grab Indonesia merupakan perusahaan yang bergerak dibidang layanan jasa transportasi berbasis online. Grab didirikan pada tahun 2011 oleh Anthony Tan dan Tan Hooi di Malaysia, Grab sendiri telah hadir di Indonesia pada bulan Juni 2012. Grab memiliki banyak pilihan layanan jasa transportasi mulai dari GrabTaxi, GrabCar, GrabBike hingga GrabExpress untuk memenuhi kebutuhan pelanggannya. GrabBike merupakan salah satu penyedia layanan jasa transportasi online khususnya sepeda motor. GrabBike memanfaatkan teknologi internet berbasis aplikasi dalam pengoperasiannya. Aplikasi GrabBike dapat diunduh pada smartphone yang memiliki sistem operasi IOS dan Android. Dengan menggunakan aplikasi GrabBike di smartphone kemudian GrabBike akan menjemput dan mengantar pelanggan sampai pada tempat tujuannya. Meskipun GrabBike menawarkan kemudahan akses dalam pemesanan berbasis aplikasi online, namun GrabBike tidak terlepas dari berbagai permasalahan.

$$
\text { Adanya fenomena yang }
$$

menunjukkan bahwa kepuasan pelanggan dinilai masih belum optimal seperti kualitas layanan yang kurang memuaskan dan konsumen merasa tidak mendapatkan manfaat atau nilai dari GrabBike itu sendiri.

Kualitas layanan yang dilakukan driver GrabBike masih belum optimal, secara umum masih terdapat banyak kelemahan, seperti keterlambatan waktu saat penjemputan penumpang, pembatalan pesanan secara sengaja oleh driver, profil driver tidak sesuai dengan aplikasi yang terdaftar, dan kurang ramahnya driver terhadap penumpang.

Selain itu, nilai pelanggan yang dimaksud disini adalah nilai atau manfaat dengan biaya yang harus dikeluarkan setelah menggunakan jasa GrabBike dinilai masih belum optimal seperti perbandingan tarif antara jam sibuk atau kerja dengan jam tidak sibuk atau free- time, dan perbandingan tarif dengan penyedia jasa transportasi ojek online lainnya.

Tujuan penelitian adalah untuk mengetahui pengaruh kualitas layanan dan nilai pelanggan terhadap kepuasan pelanggan GrabBike Di Universitas Krisnadwipayana

\section{LANDASAN TEORI}

\section{Kepuasan Pelanggan}

Kata kepuasan (satisfaction) berasal dari bahasa Latin "satis" (cukup atau memadai) dan "facio" (melakukan atau membuat). Jika diartikan secara sederhana kepuasan sebagai upaya dalam memuaskan sesuatu untuk konsumen hingga dalam tingkatan yang cukup. Menurut Kotler dan Keller (2014), “Kepuasan pelanggan adalah perasaan senang ataupun kecewa yang muncul setelah membandingkan antara kinerja atau hasil suatu produk terhadap hasil atau kinerja yang diharapkan".

Menurut Sungadji dan Sophia (2013), "kepuasan diartikan sebagai adanya kesamaan antara kinerja produk dan layanan yang diterima dengan kinerja produk dan layanan yang diharapkan konsumen".

Menurut Hawkins \& Looney dalam Tjiptono (2011), indikator terbentuknya kepuasan pelanggan terdiri dari : 1). Kesesuaian harapan; Merupakan tingkat kesesuaian antara kinerja produk yang diharapkan oleh konsumen dengan yang dirasakan oleh konsumen, meliputi : a). Produk yang diperoleh sesuai atau melebihi dengan yang diharapkan. b). Layanan oleh karyawan yang diperoleh sesuai atau melebihi dengan yang diharapkan. c). Fasilitas penunjang yang didapat sesuai atau melebihi dengan yang diharapkan. 2). Minat berkunjung kembali; Merupakan kesediaan konsumen untuk berkunjung kembali atau melakukan pembelian ulang terhadap produk terkait, meliputi : a). Berminat untuk berkunjung kembali karena layanan yang diberikan 
oleh karyawan memuaskan. b). Berminat untuk berkunjung kembali karena nilai dan manfaat yang diperoleh setelah mengkonsumsi produk. c). Berminat untuk berkunjung kembali karena fasilitas penunjang yang disediakan memadai. 3). Kesediaan merekomendasikan; Merupakan kesediaan konsumen unrtuk merekomendasikan produk yang telah dirasakannya kepada teman atau keluarga, meliputi : a). Menyarankan teman atau kerabat untuk membeli produk yang ditawarkan karena layanan yang memuaskan. b). Menyarankan teman atau kerabat untuk membeli produk yang ditawarkan karena fasilitas penunjang yang disediakan memadai. c). Menyarankan teman atau kerabat untuk membeli produk yang ditawarkan karena nilai atau manfaat yang didapat setelah mengkonsumsi sebuah produk jasa.

Strategi dalam menciptakan kepuasan konsumen merupakan strategi yang akan digunakan oleh perusahaan guna meraih dan meningkatkan kepuasan melalui peningkatan pangsa pasar, penjualan dan jumlah pelanggan. Menurut Tjiptono (2011), Strategi kepuasan konsumen yang dapat diterapkan pada perusahaan agar dapat meningkatkan kepuasan konsumen antara lain adalah: 1). "Relationship marketing; Pada strategi ini, hubungan transaksi yang terjadi antara penyedia jasa dan pelanggan akan terus berlanjut dan tidak hanya berakhir setelah penjualan atau layanan telah selesai. Faktor yang digunakan guna menciptakan relationship marketing adalah diciptakannya customer database, dimana daftar nama pelanggan yang perlu dibina hubungannya dalam jangka panjang. Database tidak hanya berisikan nama pelanggan, namun dapat mencakup hal-hal penting lainnya seperti jumlah dan frekuensi pada pembelian. 2). Strategi superior service; Perusahaan yang menerapkan strategi ini berusaha untuk menawarkan layanan yang lebih unggul dari para pesaingnya. Untuk mewujudkannya dibutuhkan dana yang cukup besar, kemampuan pada sumber daya manusia serta usaha yang gigih, maka perusahaan dengan layanan superior akan meraih laba dan tingkat pertumbuhan yang lebih besar dari para pesaingnya yang juga memberikan layanan yang unggul. 3). Strategi unconditional; Pada strategi ini, komitmen untuk mengusung kepuasan pada konsumen yang menjadi gilirannya akan menjadi sumber dinamisme dalam penyempurnaan kualitas jasa atau layanan dan kinerja pada perusahaan. Selain itu, peningkatan motivasi para karyawan guna mencapai tingkat kinerja yang lebih baik lagi dari sebelumnya. 4). Strategi penanganan keluhan yang efektif; Pengendalian keluhan yang baik secara efektif dapat memberikan kesempatan untuk mengubah pelanggan yang tidak puas menjadi pelanggan yang puas atau bahkan dapat menjadi pelanggan pribadi. 5). Strategi peningkatan kinerja perusahaan; Strategi peningkatan kinerja perusahaan merupakan penyempurnaan proses dan produk jasa melalui upaya perbaikan berkesinambungan, pengamatan serta pengukuran pada kepuasan pelanggan secara berkerkelanjutan, mengamalkan pendidikan dan pelatihan mengenai komunikasi serta membangun tim kerja lintas fungsional, sehingga diharapkan wawasan dan pengalaman karyawan dapat semakin luas. 6). Quality function deployment; Quality function deployment adalah praktik untuk menyusun suatu proses sebagai respon terhadap kebutuhan konsumen dan berusaha mengimplementasikan apa yang dibutuhkan pelanggan menjadi apa yang dihasilkan oleh perusahaan. Hal ini dijalankan dengan melibatkan pelanggan dalam proses peningkatan suatu produk termasuk jasa. Dengan begitu memungkinkan suatu perusahaan dapat mengutamakan kebutuhan konsumen dan menemukan respon kebutuhan secara inovatif". 


\section{Kualitas Layanan}

Menurut Mauludin (2013), "Kualitas layanan adalah seberapa jauh perbedaan yang dihasilkan antara kenyataan dengan ekspektasi pelanggan atas layanan yang diterima atau diperoleh". Menurut Tjiptono (2014), "Kualitas layanan adalah ukuran seberapa baik tingkat layanan yang mampu diberikan kepada pelanggan sesuai dengan ekspektasinya". Jika jasa atau layanan yang diterima atau dirasakan sesuai dengan harapan konsumen, maka kualitas yang dihasilkan oleh jasa atau layanan dipersepsikan baik dan memuaskan. Apabila jasa atau layanan yang diterima mampu melampaui ekspektasi konsumen, maka kualitas yang dihasilkan oleh jasa atau layanan dipersepsikan sebagai kualitas layanan yang unggul, sedangkan menurut Goeth dan Davis dalam Tjiptono (2014), "Kualitas layanan merupakan suatu kondisi yang berhubungan dengan produk, jasa, manusia, proses, dan lingkungan yang dapat memenuhi atau melebihi harapan pelanggan".Kualitas layanan merupakan segala aspek jasa atau layanan yang disampaikan suatu perusahaan dengan tujuan memenuhi ekspektasi para pelanggan berupa kemudahan, kecepatan, kemampuan, hubungan,

Menurut Garvin dalam Tjiptono (2014), "Kualitas layanan tergantung pada orang-orang yang menilainya, sehingga produk yang dikatakan paling memuaskan dapat menjadi preferensi yang menjadi produk dengan kualitas paling tinggi seseorang kepada lainnya".

Menurut Zeithaml \& Parasuraman dalam Hardiansyah (2011), Kualitas layanan dapat diukur berdasarkan lima dimensi, yaitu: 1). "Berwujud (tangible); Berwujud (tangible) adalah wujud fisik secara nyata yang termasuk di dalamnya yaitu pegawai, peralatan, fasilitas, sarana informasi atau komunikasi. Tangible juga merupakan kedisiplinan pegawai, tampilan fisik saat melakukan layanan, peralatan, ketersediaan sarana-prasarana, kemudahan memperoleh atau melakukan komunikasi dan informasi. Menurut Tjiptono (2014), "Hal yang menyangkut tangible meliputi sumber daya manusia, penampilan fisik, peralatan atau perlengkapan, fasilitas layanan dan materi komunikasi perusahaan". Dimensi tangible terdiri dari atas: a). Penampilan petugas atau aparatur dalam melayani semua pelanggan; b). Kenyamanan pada tempat melakukan layanan; c). Kemudahan yang didapatkan dalam melakukan proses layanan; d). Kedisiplinan yang ditunjukkan oleh petugas atau aparatur dalam melakukan layanan; e). Kemudahan pelanggan mengakses dalam permohonan layanan; f). Penggunaan alat yang dapat membantu dalam layanan. 2). Kehandalan (reliability); Kehandalan (reliability) adalah kemampuan suatu perusahaan dalam memberikan layanan yang telah dijanjikan secara akurat dan memuaskan. Selain itu, relaiability juga dapat meliputi kemampuan perusahaan untuk melaksanakan layanan yang dijanjikan, ketepatan dan keakuratan, metode layanan, kemampuan pegawai dalam memberikan solusi dan mengatasi masalah yang dihadapi serta kemampuan mengoperasionalkan berbagai peralatan layanan. Menurut Tjiptono (2014), "Reliability adalah kemampuan yang dapat dilakukan oleh perusahaan dalam menyampaikan layanan yang telah dijanjikan dengan akurat dan terpercaya". Dimensi reliability terdiri atas: a). Kecermatan petugas dalam melayani pelanggan; b). Memiliki standar layanan yang jelas; c). Kemampuan petugas atau aparatur dalam menggunakan alat bantu dalam proses layanan; d). Keahlian petugas atau aparatur dalam menggunakan alat bantu dalam proses layanan. 3). Ketanggapan (responsiviness); Ketanggapan (responsiviness) adalah sejauh mana sebuah perusahaan dapat melihat kebutuhan dan keinginan pasar serta respon terhadap keluhan para pelanggan. "Responsiviness berhubungan dengan kesediaan dan kemampuan penyedia layanan dalam membantu para 
pelanggan serta menanggapi permintaan konsumen dengan segera" (Tjiptono, 2014). Responsiviness merupakan salah satu dimensi paling dinamis. Salah satunya adalah keinginan karyawan dalam membantu dan memberikan layanan kepada para pelanggan dengan cepat. Dimensi responsiviness terdiri atas: a). Menanggapi setiap pelanggan yang ingin mendapatkan layanan; b). Petugas atau aparatur melakukan layanan dengan cepat; c). Petugas atau aparatur melakukan layanan dengan tepat; d). Petugas atau aparatur melakukan layanan dengan cermat. 4). Jaminan (assurance); Jaminan (assurance) merupakan dimensi yang berhubungan dengan kemampuan yang dimiliki oleh perusahaan dan perilaku karyawan dalam menumbuhkan rasa percaya dan yakin kepada pelanggannya. Menurut Tjiptono (2014), "Assurance berkenaan dengan pengetahuan dan kesopanan karyawan serta kemampuan yang dimiliki dalam menciptakan rasa percaya dan keyakinan pada pelanggan". Dimensi assurance terdiri atas: a). Petugas atau aparatur memberikan jaminan tepat waktu dalam layanan; b). Petugas atau aparatur memberikan jaminan biaya dalam layanan; c). Petugas atau aparatur memberikan jaminan legalitas dalam layanan; d). Petugas atau aparatur memberikan jaminan kepastian biaya dalam layanan. 5). Empati (emphaty); Empati (emphaty) adalah sifat dan kemampuan yang dimiliki perusahaan untuk memberikan perhatian penuh kepada pelanggan, memiliki komunikasi yang baik, memberikan kemudahan kontak yang dapat dihubungi dan memahami kebutuhan pelanggan secara individual. Secara umum, dimensi ini merupakan dimensi kurang penting di mata para pelanggan. Namun bagi kelompok pelanggan dengan kelas atas, dimensi ini dapat menjadi dimensi yang sangat penting. Menurut Tjiptono (2014), "Perusahaan harus memahami permasalahan para pelanggan dan bergerak untuk kepentingan pelanggan, memberikan layanan personal kepada pelanggan, serta memilih jam operasional yang sesuai". Dimensi emphaty terdiri atas: a). Mengutamakan kepentingan masyarakat; b). Petugas atau aparatur melayani dengan sikap ramah; c). Petugas atau aparatur melayani dengan sopan santun; d). Petugas atau aparatur melayani dengan tidak diskriminatif (membeda-bedakan); e). Petugas atau aparatur melayani dan menghargai setiap pelanggan".

\section{Nilai Pelanggan}

Menurut Kotler (2012),"Nilai pelanggan adalah selisih perbandingan antara nilai pelanggan total dengan biaya pelanggan total". Nilai pelanggan total adalah sekumpulan manfaat yang diharapkan oleh pelanggan dari produk atau jasa tertentu, sedangkan biaya pelanggan total adalah sekumpulan biaya yang diharapkan oleh konsumen yang dikeluarkan untuk mengevalusi, mendapatkan, menggunakan, dan membuang produk atau jasa".

Menurut Tjiptono (2011), "Nilai pelanggan merupakan keseluruhan penilaian pelanggan tentang kegunaan suatu produk berdasarkan persepsi tentang apa yang diterima dan apa yang diberikan". Persepsi pembeli tentang nilai yang menggambarkan sebuah perbandingan antara keuntungan atau manfaat yang mereka rasakan dalam produk atau jasa dengan biaya yang mereka rasakan saat membayar harga produk atau jasa tersebut. Menurut Butz dan Goodstein dalam Tjiptono (2014), "Nilai pelanggan adalah ikatan emosional yang terjalin antara pelanggan dan produsen setelah pelanggan menggunakan produk dan jasa dari perusahaan dan memberikan nilai tambah atau manfaat dari produk dan jasa tersebut".

Menurut Sweeney \& Soutar dalam Ricky (2017), dimensi nilai pelanggan terdiri atas 4 aspek utama: 1). "Nilai emosional (emotional value), Yaitu utilitas yang berasal dari perasaan atau emosi positif yang ditimbulkan dari 
mengkonsumsi produk. Atribut dari nilai emosional meliputi kemampuan suatu produk untuk menimbulkan rasa ingin mengkonsumsi produk tersebut dan kemampuan sebuah produk untuk menciptakan rasa senang atau puas terhadap produk tersebut. Semakin tinggi nilai emosional yang tercipta maka akan semakin tinggi pula kepuasan konsumen. 2). Nilai sosial (social value), Yaitu utilitas yang didapatkan dari kemampuan produk untuk meningkatkan konsep diri sosial konsumen. Atribut dari nilai sosial meliputi kemampuan suatu produk untuk menimbulkan rasa bangga kepada konsumen dan kemampuan suatu produk untuk menimbulkan kesan yang baik kepada konsumen. Semakin tinggi penilaian konsumen dari segi sosial terhadap suatu produk atau jasa maka akan semakin tinggi pula kepuasan yang terbentuk. 3). Nilai kualitas atau kinerja (quality/performance value), Yaitu utilitas yang didapatkan konsumen dari produk dikarenakan reduksi biaya jangka pendek dan biaya jangka panjang. Atribut dari nilai kualitas meliputi manfaat yang diperoleh konsumen setelah mengkonsumsi produk tersebut dan konsistensi layanan oleh karyawan perusahaan. Semakin tinggi penilaian konsumen terhadap kualitas dan kinerja atas sebuah produk atau jasa maka akan semakin tinggi pula tingkaat kepuasan konsumen. 4). Nilai terhadap biaya (price/value for money), Yaitu utilitas yang diperoleh konsumen dari persepsi terhadap kualitas dan kinerja yang diharapkan atas produk. Atribut dari nilai terhadap biaya meliputi perbandingan biaya yang dikeluarkan dengan manfaat yang diperoleh dari produk tersebut dan perbandingan biaya yang dikeluarkan untuk produk tersebut dengan produk serupa dari perusahaan lain. Jika manfaat yang diperoleh lebih tinggi dari harga suatu produk maka akan tercipta kepuasan konsumen".

Menurut Tjiptono (2014) mengidentifikasikan delapan tipe nilai pelanggan utama dalam pengalaman konsumsi sebagai berikut: 1). "Efisiensi (efficiency value); Rasio output/input atau convenience value adalah nilai yang dihasilkan dari penggunaan secara aktif berbagai cara untuk mewujudkan tujuan berorientasi pribadi. Oleh sebab itu, efisiensi tidak bisa dipisahkan dari tindakan pemakaian produk demi pencapaian tujuan pribadi. 2). Kualitas (excellent value); Tipe nilai yang ditujukan kepada pemuasan tujuan pribadi, namun mencakup respon yang bersifat reaktif. Kualitas menyangkut respon reaktif berupa mengagumi obyek atau pengalaman tertentu dikarenakan kapasitas ekstrinsiknya untuk berperan sebagai sarana dalam mewujudkan tujuan berorientasi pribadi. 3). Kesuksesan (political value); Nilai yang mencakup upaya aktif mengejar kesuksesan yang diberikan orang lain. Dalam konteks ini, politik merupakan penggunaan produk atau pengalaman konsumsi pribadi sebagai sarana atau cara untuk mendapatkan respon positif dari orang lain. Perilaku konsumsi seperti mengikuti program doktoral mencerminkan nilai politik. 4). Reputasi (esteem value); Nilai politis yang bersifat reaktif dan tercermin dalam bentuk reputasi atau penghargaan sosial. Esteem value didapatkan melalui kontemplasi reaktif atas status atau prestise seseorang, sebagaimana tercermin dalam pendapat positif dari orang lain. 5). Kesenangan (play value); Mencerminkan pengalaman self-oriented yang aktif dan dinikmati demi kepentingan sendiri. 6). Keindahan (esthetic value); Mirip dengan play value, hanya saja perbedaan utamanya terletak pada karakteristik nilai estetis yang didapatkan sebagai hasil apresiasi reaktif. 7). Kebajikan (morality value); Mencerminkan active other-oriented value. Tindakan etis misalnya, melakukan sesuatu demi kepentingan orang lain, yakni menyangkut bagaimana dampaknya terhadap orang lain atau bagaimana reaksi orang lain terhadap tindakan bersangkutan. 8). Keyakinan (spiritual value); Mirip dengan moralitas, namun fokusnya lebih 
pada pencapaian intristic other oriented value".

\section{METODE PENELITIAN}

Metode penelitian yang digunakan adalah metode penelitian kuantitatif, jumlah populasi 250 orang dengan menggunakan rumus slovin didapat sampel 71 responden. Data dikumpulkan dengan menggunakan metode kuesioner, uji instrumen data, dan teknik analisis data yang digunakan adalah analisis regresi linier berganda.

\section{HASIL PENELITIAN}

\section{Uji Validitas}

Menurut Sugiyono (2016),

"Instrumen yang valid atau tepat berarti alat yang digunakan untuk mendapatkan data (mengukur) itu valid, dimana instrument itu dapat digunakan untuk mengukur apa yang ingin diukur". Validitas dapat dilakukan dengan mengkorelasikan antar item skor instrumen dalam suatu faktor dan mengkorelasikan antar skor faktor dengan skor total. Apabila korelasi tiap faktor instrumen besarnya 0,3 atau lebih maka instrumen tersebut dinyatakan valid atau variabel yang kuat. Pengujian validitas dilakukan berdasarkan analisis item, yaitu mengkorelasikan skor setiap pertanyaan dengan skor totalnya.

Tabel 1. Hasil Uji Validitas Instrumen Data

\begin{tabular}{|c|c|c|c|c|c|}
\hline \multirow[b]{2}{*}{ Item } & \multicolumn{3}{|c|}{ R hitung } & \multirow[b]{2}{*}{ R kritis } & \multirow[b]{2}{*}{ Kesimpulan } \\
\hline & $\begin{array}{l}\text { Kualitas } \\
\text { Layanan }\end{array}$ & $\begin{array}{c}\text { Nilai } \\
\text { Pelanggan }\end{array}$ & $\begin{array}{l}\text { Kepuasan } \\
\text { Pelanggan }\end{array}$ & & \\
\hline 1 & 0.890 & 0.791 & 0.763 & 0,300 & Valid \\
\hline 2 & 0.815 & 0.860 & 0.649 & 0,300 & Valid \\
\hline 3 & 0.818 & 0.864 & 0.710 & 0,300 & Valid \\
\hline 4 & 0.796 & 0.794 & 0.801 & 0,300 & Valid \\
\hline 5 & 0.814 & 0,773 & 0.637 & 0,300 & Valid \\
\hline 6 & 0.836 & 0,798 & 0.736 & 0,300 & Valid \\
\hline 7 & 0.773 & 0,780 & 0.663 & 0,300 & Valid \\
\hline 8 & 0.799 & 0,882 & 0.729 & 0,300 & Valid \\
\hline 9 & 0,790 & 0,859 & - & 0,300 & Valid \\
\hline 10 & 0,818 & 0.802 & - & 0,300 & Valid \\
\hline 11 & 0,816 & - & - & 0,300 & Valid \\
\hline 12 & 0,808 & - & - & 0,300 & Valid \\
\hline 13 & 0,796 & - & - & 0,300 & Valid \\
\hline 14 & 0,885 & - & - & 0,300 & Valid \\
\hline 15 & 0.836 & - & - & 0,300 & Valid \\
\hline
\end{tabular}

Sumber: Data diolah

Berdasarkan Tabel 1, hasil uji validitas kualitas layanan, nilai pelanggan dan kepuasan pelanggan menunjukkan bahwa seluruh butir/item pada masingmasing variabel yang diteliti telah berada di atas 0,300 sehingga butir/item pernyataan yang digunakan dalam penelitian ini dikatakan valid dan layak digunakan untuk seluruh responden yang telah ditargetkan.

\section{Uji Reliabilitas}

Jika alat ukur telah dinyatakan valid, selanjutnya reliabilitas alat ukur tersebut diuji. Reliabilitas adalah suatu nilai yang menunjukan konsistensi suatu alat pengukur didalam mengukur gejala yang sama. Instrument yang realibel adalah instrument yang bila mana dicobakan secara berulang ulang kepada berkelompok yang sama akan menghasilkan data yang sama dengan asumsi tidak terdapat perubahan psikologis pada responden. 
Untuk mengukur reliabilitas dilakukan dengan melihat Alpha Cronbach. Menurut Ghozali (2016), "Suatu instrumen variabel dikatakan reliabel apabila nilai alpha lebih besar dari 0,60 ".

Tabel 2. Hasil Uji Reliabiltas

\begin{tabular}{lccc}
\hline \multicolumn{1}{c}{ Keteranga } & Koefisien Alpha $(\boldsymbol{\alpha})$ & Standar & Kesimpulan \\
\hline Kualitas Layanan & 0,965 & 0,60 & Reliabel \\
Nilai Pelanggan & 0,957 & 0,60 & Reliabel \\
Kepuasan Pelanggan & 0,899 & 0,60 & Reliabel \\
\hline
\end{tabular}

Sumber: Data diolah

Berdasarkan Tabel 2, pada kualitas layanan koefisien alpha sebesar 0,965 > 0,60 , sedangkan pada nilai pelanggan koefisien alpha sebesar 0,957>0,60, dan kepuasan pelanggan koefisien alpha sebesar $0,899>0,60$. Jika dilihat berdasarkan angka-angka realibilitas cronbach's alpha tersebut tampak bahwa seluruh pernyataan yang ada membentuk ukuran yang reliabel.

\section{Hasil Penelitian}

Tabel 3. Pengaruh Kualitas Layanan dan Nilai Pelanggan Terhadap Kepuasan Pelanggan Grab Bike di Unkris

\begin{tabular}{|c|c|c|c|c|c|c|}
\hline \multirow{2}{*}{$\begin{array}{c}\text { Hubungan } \\
\text { Variabel }\end{array}$} & \multicolumn{6}{|c|}{ Parameter } \\
\hline & $\begin{array}{c}\text { Mult. } \\
\text { R }\end{array}$ & $\begin{array}{c}\mathbf{R} \\
\text { Square }\end{array}$ & $\begin{array}{l}\text { Kons } \\
\text { tanta }\end{array}$ & Coef. B & Sig & $\alpha$ \\
\hline $\begin{array}{l}\text { Kualitas } \\
\text { Layanan }\end{array}$ & \multirow{2}{*}{0.859} & \multirow{2}{*}{0.739} & \multirow{2}{*}{5.430} & 0.257 & \multirow{2}{*}{0.000} & \multirow{2}{*}{$5 \%$} \\
\hline $\begin{array}{c}\text { Nilai } \\
\text { Pelanggan }\end{array}$ & & & & 0.260 & & \\
\hline \multicolumn{7}{|c|}{ Pengujian Signifikan } \\
\hline \multicolumn{7}{|c|}{ F hitung $>$ F Tabel $=96.038>3.132$} \\
\hline
\end{tabular}

Dari Tabel 3, terlihat bahwa nilai regresi memiliki nilai signifikansi 0,000 , nilai ini lebih kecil dari 0,05 , ini berarti hipotesis penelitian yang menyatakan kualitas layanan dan nilai pelanggan secara bersama sama memiliki pengaruh yang signifikan terhadap kepuasan pelanggan diterima. Dalam penelitian ini $F$ hitung memiliki nilai 96,038 sedangkan $\mathrm{F}$ tabel memiliki nilai 3,132 dapat diartikan $F$ hitung lebih besar dari $\mathrm{F}$ tabel, sehingga hipotesis penelitian diterima.

Nilai $\mathrm{R}^{2}$ sebesar 0.739 , artinya kontribusi yang yang diberikan oleh variabel kualitas layanan dan nilai pelanggan terhadap kepuasan pelanggan sebesar $73,9 \%$, sedangkan sisanya sebesar
$26.1 \%$ disumbangkan oleh variabel lain yang tidak diteliti.

Persamaan regresi yang terjadi adalah sebagai berikut:

$$
Y=5.430+0.257 X_{1}+0.260 X_{2}
$$

Nilai koefisien regresi kualitas layanan sebesar 0,257 yang bernilai positif artinya terdapat hubungan yang searah antara kualitas layanan dan kepuasan pelanggan.

Nilai koefisien regresi nilai pelanggan sebesar 0,260 yang nilainya positif, berarti terdapat hubungan yang searah antara nilai pelanggan dan kepuasan pelanggan. 


\section{KESIMPULAN DAN SARAN}

\section{Kesimpulan}

Berdasarkan hasil penelitian dapat diambil kesimpulan sebagai berikut : Hasil penelitian menunjukkan bahwa variabel kualitas layanan dan nilai pelanggan berpengaruh secara positif dan signifikan terhadap variabel kepuasan pelanggan.

\section{Saran}

Berdasarkan hasil penelitian dan pembahasan, maka saran yang dapat diberikan adalah sebagai berikut: 1). Indikator variabel kualitas layanan yang perlu ditingkatkan oleh PT. Grab Indonesia adalah jaminan seperti memberikan rasa aman pada penumpang, tidak ugal ugalan selama di perjalanan dan driver dapat dipercaya. Indikator variabel nilai pelanggan yang perlu ditingkatkan oleh PT. Grab Indonesia adalah nilai sosial dan nilai atas biaya seperti mampu meningkatkan harga diri penumpang, serta memiliki harga yang terjangkau, murah dan sesuai dengan layanannnya. Indikator variabel kepuasan pelanggan yang perlu ditingkatkan adalah minat berkunjung kembali seperti mampu memberikan layanan yang memuaskan dan fasilitas yang disediakan sudah memadai. 2). Bagi peneliti selanjutnya diharapkan meneliti variabel lain yang mempengaruhi kepuasan pelanggan seperti kualitas produk, harga, citra merek, promosi, lokasi dan yang lainnya.

\section{DAFTAR PUSTAKA}

Etta, Mamang Sangadji \& Sopiah, 2013, Perilaku Konsumen Pendekatan
Praktis Disertai Ilmu Manajemen, Himpunan Jurnal Penelitian, Yogyakarta : Andi Offset

Fauji, Ricky, 2017, Pengaruh Kualitas Layanan, dan Nilai Pelanggan Terhadap Kepuasan Konsumen Gojek (Studi Pada Konsumen Go-jek Pengguna Layanan Go-ride di Kota Yogyakarta), (Skripsi), Yogyakarta: Fakultas Ekonomi Universitas Sanata Dharma.

Ghozali, Imam, 2016, Aplikasi Analisis Multivariate Dengan Program IBM SPSS 23, Edisi Ke-8, Cetakan KeVIII, Semarang : Badan Penerbit Universitas Diponegoro

Hardiansyah, 2011, Kualitas Layanan Publik, Yogyakarta : Gaya Media

Kotler, Philip, 2012, Manajemen Pemasaran, Jilid I dan II, PT. Indeks, Jakarta

Kotler, Philip R., Bowen, John T \& Makens, James, 2014, Marketing For Hospitaly and Tourism, Sixth Edition, Pearson Eduction Limited

Mauludin, Hanif, 2013, Marketing Research: Panduan Bagi Manajer, Pimpinan Perusahaan Organisasi, Penerbit Elex Media Komputindo, Jakarta

Sugiyono, 2016, Metode Penelitian Pendidikan Penekatan Kuantitatif, Kualitatif, dan $R \& D$, Bandung: Alfabeta

Tjiptono, Fandy, 2011, Strategi Pemasaran. Edisi Ke-3, Yogyakarta: Andi Offset , 2014, Pemasaran Jasa, Edisi Ke-3, Yogyakarta : CV. Andi Offset. 